\title{
Interrelationships between morphometric variables and rounded fish body yields evaluated by path analysis ${ }^{1}$
}

\author{
Rafael Vilhena Reis Neto ${ }^{2}$, Rilke Tadeu Fonseca de Freitas ${ }^{2}$, Moacyr Antonio Serafini ${ }^{3}$, \\ Adriano Carvalho Costa ${ }^{2}$, Thiago Archangelo Freato ${ }^{4}$, Priscila Vieira Rosa ${ }^{3}$, Ivan Bezerra \\ Allaman ${ }^{5}$
}

\footnotetext{
1 Support: CNPq, INCT-CA and FAPEMIG.

2 Universidade Federal de Lavras.

3 Instituto Federal Do Espírito Santo - Campus Santa Maria.

${ }^{4}$ Empresa de Pesquisa Agropecuária de Minas Gerais.

5 Universidade Estadual de Santa Cruz - UESC.
}

\begin{abstract}
The objective of this study was to verify which morphometric measures and ratios are more directly associated with the weight and body yields of rounded fish. A total of 225 specimens of rounded fish (59 pacus, 61 tambaquis, 52 tambacus and 53 paquis) with average weight of $972.43 \mathrm{~g}$ ( $\pm 115.52 \mathrm{~g}$ ) were sampled, stunned, slaughtered, weighed, measured, and processed for morphometric and processing yield analysis. The morphometric measures taken were: standard length (CP); head length (CC); head height (AC); body height (A1); and body width (L1). For completeness, the following morphometric ratios were calculated: CC/CP, AC/CP, A1/CP, L1/CP, CC/A1, AC/A1, L1/A1, CC/AC and L1/CC. The yields of carcass, filet, rib and filet with rib were estimated after processing. Initially, a "stepwise" procedure was performed in order to eliminate multicollinearity problems among the morphometric variables, and the phenotypic correlations were then calculated for the dependent variables (weight and body yields) and independent variables (morphometric measurements and ratios). These correlations were later deployed in direct and indirect effects through path analysis, and the direct and indirect contributions of each variable were measured in percentage terms. The CC and A1 measures were important for determining the weight of rounded fish. The CC/A1 ratio was the variable most directly associated with carcass yield. For filet, filet with rib and rib yields, the L1/CC ratio was found to be more appropriate and can be used directly.
\end{abstract}

Key Words: animal breeding, carcass, Colossoma macropomum, direct effect, Piaractus mesopotamicus

\section{Introduction}

Round fish (species and hybrids of the Colossoma and Piaractus genera) are easy to cultivate and present good animal performance, meat of excellent quality, low demand for water quality, resistance to disease and are valued in recreational fishing (Carneiro \& Abimorad, 2004; Jomori et al., 2008; Signor et al., 2010), thus representing $82 \%$ of the total native fish reared in Brazil (IBAMA, 2005).

The fish processing industry places no value on the fish carcass characteristics, and still bases business decisions with its suppliers on the fish weight. However, the consumer market prefers the finest cuts such as filet and, in the case of round fish, the ribs, which served mainly as an aperitif, are much appreciated in the North and Midwest regions of Brazil. Thus, studies of fish body yields have great importance in estimates of productivity, by reducing costs and increasing profits for both farmer and industry (Souza et al., 1999).

Breeding programmes that are aimed at body yield increase present difficulties, since the direct measurement

Received August 19, 2011 and accepted February 27, 2012.

Corresponding author: rafaneto2003@yahoo.com.br results in sacrifice of the animal and hence in the loss of a potential breeder within the group (Crepaldi et al., 2008). In this context, studies of some alternatives that enable the production of fish with better carcass traits have focused primarily on the use of body measurements as selection criteria mainly related to carcass and filet yields (Silva et al., 2009).

Correlation of body yields with morphometric measurements has been the subject of several studies for some fish species (Freato et al., 2005; Diodatti et al., 2008). However, this simple correlation only makes it possible to evaluate the direction and magnitude of the association between two characters, without providing necessary information concerning the direct and indirect effects of a group of characters in relation to a dependent variable of major importance (Cruz, 2001).

"Path analysis" is a device that a breeding researcher can use to break the correlation of direct and indirect effects (Cruz \& Carneiro, 2003) through basic variables such as body yields, and explanatory variables such as morphometric ratios and measures, providing a better 
understanding of the reasons for the associations between these traits (Costa, 2011).

This study used path analysis of the phenotypic correlations to verify which morphometric measures and ratios would be more directly associated with body weight and yields of round fish (pacu Piaractus mesopotamicus, tambaqui Colossoma macropomum and their hybrids).

\section{Material and Methods}

A total of 225 specimens of round fish, weighing $972.43 \pm 115.52 \mathrm{~g}$ obtained from the Aquaculture Station of the Instituto Federal do Espírito Santo, Campus Colatina, were used. Of these fish, 59 were of specimens of pacu, 61 of tambaqui, 52 of tambacu (from the crossing of male pacu with female tambaqui) and 53 of paqui (from the crossing of male tambaqui with female pacu), all reared in the same earth pond. To keep the genetic groups separated during cultivation, polypropylene mesh $(9 \times 9 \mathrm{~mm})$ was used to divide the pond into four parts of equal size $(6 \mathrm{~m} \times 11 \mathrm{~m})$, each with an individual supply of water, where fish were fed a commercial diet incorporating $320 \mathrm{~g}$ of crude protein per $\mathrm{kg}$ feed.

To obtain the morphometric measurements and body yields, the sampled fish were stunned by a cut at the spinal cord following the protocol described by Pedrazzani et al. (2009), sacrificed by exsanguination, weighed, subjected to morphometric evaluation and dissected for the separation and weighing of body components.

The following morphometric measurements were evaluated: standard length (SL), measured between the anterior head extremity and the insertion of the tail fin; head length (HL), between the anterior head extremity and the end of operculum; head height (HH), between the upper and lower edges of the head; body height $(\mathrm{BH})$, measured in front of the first ray of dorsal fin; and body width (BW), measured at the first ray of the dorsal fin (Figure 1).

The standard length was measured using an ictiometer and the other measurements were taken with a caliper graded in millimeters (mm).

To complement the measurements above, the following morphometric ratios were calculated: HL/SL, HH/SL, BH/SL, BW/ SL, HL/BH, HH/BH, BW/BH, HL/HH, and BW/HL.

At dissection, the fish were weighed, gutted, the carcass (eviscerated fish) was weighed, then the skin with scales was removed with the aid of pliers in the skull-tail direction. Following this procedure, the head was separated from the trunk by means of a cross-sectional cut at the operculum end and at the pectoral fin insertion. Using a fileting knife, filet and ribs were separated from the backbone and,

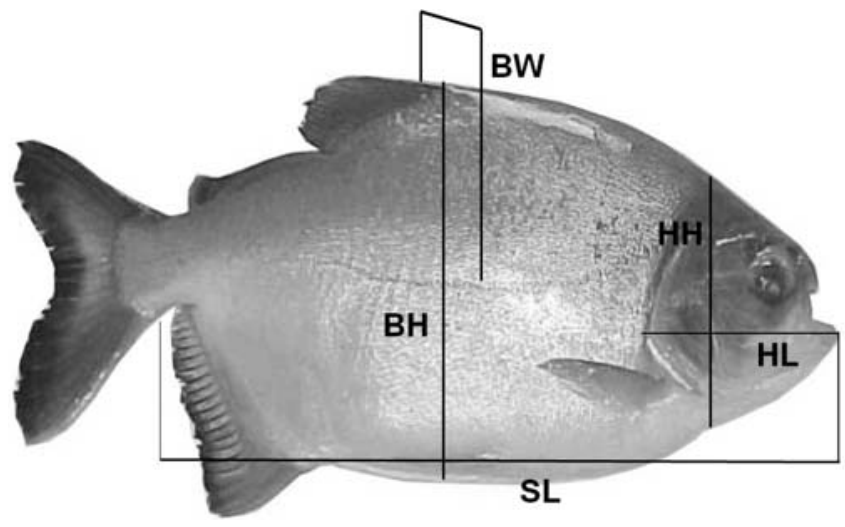

SL - standard length; HL - head length; HH - head height, BH - body height; BW - body width.

Figure 1 - Morphometric measurements of round fish.

subsequently, the filet was separated from ribs. At every step of dissecting, the products generated were weighed and the following body yields were calculated in relation to slaughter weight: carcass yield; filet with rib yield; filet yield; and rib yield.

For this study, slaughter weight and body yields obtained were considered as response (or dependent) variables and morphometric measurements and ratios as independent variables. Path coefficient estimates (direct and indirect effects) are obtained by regression equations, ie., from the system of equations solution $X^{\prime} X \hat{\beta}=X^{\prime} Y$, so it is necessary that the matrix $\mathrm{X}^{\prime} \mathrm{X}$ be properly conditioned, because multicollinearity problems may make it singular, and consequently, the least squares estimates may be unreliable (Cruz \& Carneiro, 2003). The data were therefore initially submitted to a multiple linear regression analysis, using a "stepwise" procedure, to eliminate possible effects of multicollinearity and, by the Akaike criterion (AIC), the defined independent variables were included in the path analysis for each response variable studied (Coimbra et al., 2005; Charnet et al., 2008).

Having defined the independent variables, identification via Cook's Distance was conducted for each response variable, and influential points were discarded. The correlations between the dependent and independent variables were then calculated using Pearson's linear correlation coefficient, applying Student's T test ( $\alpha=0.05$ ) to assess their significance (Charnet et al., 2008). These correlations were then deployed in direct and indirect effects by path analysis (Cruz \& Carneiro, 2003), in which direct and indirect contributions are quantified as a percentage based on the total sum of direct and indirect effects of each independent variable. All analyses were performed using the software " $R$ " version 2.13.2 for Windows. 
The interpretation of results was based on the following criteria (adapted from Loures et al., 2001): if an independent variable $(\mathrm{x})$ does not present a significant correlation coefficient with the dependent variable (y), this indicates that it is not determining the variation in y, regardless of any presence or absence of any high direct effect on y; if an independent variable $(\mathrm{x})$ has a significant correlation and high direct effect on the dependent variable (y), this indicates that it is determining the variation of $y$; and, if the independent variable (x) show a significant correlation but low direct effect on the dependent variable (y), this indicates that it should not be used alone as a determining factor for $\mathrm{y}$.

\section{Results and Discussion}

The "stepwise" procedure resulted in the inclusion of the following morphometric measures and ratios in the path analysis for each response variable studied: WEIGHT $=\mathrm{HL}$, $\mathrm{BH}, \mathrm{BW}, \mathrm{BH} / \mathrm{SL}, \mathrm{BW} / \mathrm{SL}, \mathrm{BW} / \mathrm{HL}$; carcass yield = HH, BH, BW, HH/SL, HL/BH, BW/BH; RCOST = HH/SL, BH/SL,
BW/SL, HH/BH, BW/HL; filet with rib yield = HH, BW/SL, $\mathrm{HL} / \mathrm{HH}, \mathrm{BW} / \mathrm{HL}$; filet yield = $\mathrm{HH}, \mathrm{HL} / \mathrm{HH}, \mathrm{BW} / \mathrm{HL}$.

Most correlation coefficients were significant and the determination coefficients showed values above 0.55 for the weight and body yields of round fish (Table 1), demonstrating the effectiveness of using morphometric measures and ratios in this study. Sang et al. (2009) also report that body measurements were effective in the estimation of weight and body yield in catfish Pangasianodon hypophthalmus.

The highest correlation coefficient between the morphometric variables and weight of fish was observed to be the body height measure (BH), with a value of 0.83 (Table 1 ). However, the measures with the highest direct effect percentage for weight were HL (62.09\%) and BW (57.72\%), while $\mathrm{BH}$, with the highest correlation coefficient, presented a large percentage of indirect effects (57.47\%), particularly for HL and the BW/HL ratio (Table 2), indicating that body height is important in determining weight, but should not be considered singly. Thus, HL, which had the second highest

Table 1 - Correlation coefficients, direct and sums of the indirect effects, and percentages of direct and indirect effects of morphometric measurements and ratios with weight and body yield of round fish (pacu, tambaqui, and their hybrids: tambacu and paqui)

\begin{tabular}{|c|c|c|c|c|c|c|c|}
\hline Variables & $\begin{array}{c}\text { Correlation } \\
\text { coefficient }\end{array}$ & $\mathrm{P}$ value & $\begin{array}{l}\text { Direct } \\
\text { effects }\end{array}$ & $\begin{array}{c}\text { Sums of } \\
\text { indirect effects }\end{array}$ & $\begin{array}{l}\% \text { direct } \\
\text { effects }\end{array}$ & $\begin{array}{l}\text { \% indirect } \\
\text { effects }\end{array}$ & $\mathrm{R}^{2}$ adj. \\
\hline \multicolumn{8}{|c|}{ Weight } \\
\hline HL & 0.48 & 0.000 & 1.232 & -0.752 & 62.09 & 37.91 & 0.92 \\
\hline BW & 0.21 & 0.012 & 0.785 & -0.575 & 57.72 & 42.28 & \\
\hline $\mathrm{BH} / \mathrm{SL}$ & -0.07 & 0.323 & 0.187 & -0.257 & 42.12 & 57.88 & \\
\hline $\mathrm{BW} / \mathrm{SL}$ & -0.16 & 0.019 & -2.150 & 1.990 & 51.93 & 48.07 & \\
\hline \multicolumn{8}{|c|}{ Carcass yield } \\
\hline $\mathrm{HH}$ & 0.36 & 0.000 & 0.814 & -0.454 & 64.20 & 35.80 & 0.56 \\
\hline $\mathrm{BH}$ & -0.03 & 0.691 & 0.239 & -0.269 & 47.04 & 52.96 & \\
\hline BW & -0.3 & 0.000 & -1.851 & 1.551 & 54.41 & 45.59 & \\
\hline $\mathrm{HH} / \mathrm{SL}$ & 0.19 & 0.012 & -0.602 & 0.792 & 43.18 & 56.82 & \\
\hline $\mathrm{HL} / \mathrm{BH}$ & 0.55 & 0.000 & 0.502 & 0.048 & 91.30 & 8.70 & \\
\hline \multicolumn{8}{|c|}{ Rib yield } \\
\hline $\mathrm{BW} / \mathrm{SL}$ & 0.18 & 0.012 & -0.967 & 1.147 & 45.74 & 54.26 & \\
\hline $\mathrm{HH} / \mathrm{BH}$ & -0.25 & 0.000 & 2.876 & -3.126 & 47.92 & 52.08 & \\
\hline $\mathrm{BW} / \mathrm{HL}$ & 0.58 & 0.000 & 1.375 & -0.795 & 63.37 & 36.63 & \\
\hline \multicolumn{8}{|c|}{ Filet with rib yield } \\
\hline $\mathrm{HH}$ & -0.45 & 0.000 & -0.256 & -0.194 & 56.82 & 43.18 & 0.79 \\
\hline BW/SL & 0.49 & 0.000 & -0.166 & 0.656 & 20.21 & 79.79 & \\
\hline $\mathrm{HL} / \mathrm{HH}$ & -0.6 & 0.000 & -0.302 & -0.298 & 50.38 & 49.62 & \\
\hline $\mathrm{BW} / \mathrm{HL}$ & 0.84 & 0.000 & 0.702 & 0.138 & 83.59 & 16.41 & \\
\hline \multicolumn{8}{|c|}{ Filet yield } \\
\hline $\mathrm{HH}$ & -0.36 & 0.000 & -0.144 & -0.216 & 39.96 & 60.04 & 0.7 \\
\hline $\mathrm{HL} / \mathrm{HH}$ & -0.54 & 0.000 & 0.240 & 0.360 & 40.00 & 60.00 & \\
\hline
\end{tabular}

Morphometric measurements: standard length (SL), head length (HL), head height (HH), body height (BH), body width (BW). Morphometric ratios: HH/SL, BH/SL, $\mathrm{BW} / \mathrm{SL}, \mathrm{HL} / \mathrm{BH}, \mathrm{HH} / \mathrm{BH}, \mathrm{BW} / \mathrm{BH}, \mathrm{HL} / \mathrm{HH}, \mathrm{BW} / \mathrm{HL}$. 
Table 2 - Estimates of direct and indirect effects, obtained by path analysis, between the morphometric measurements and ratios and weight and body yields of round fish (pacu, tambaqui, and their hybrids: tambacu and paqui)

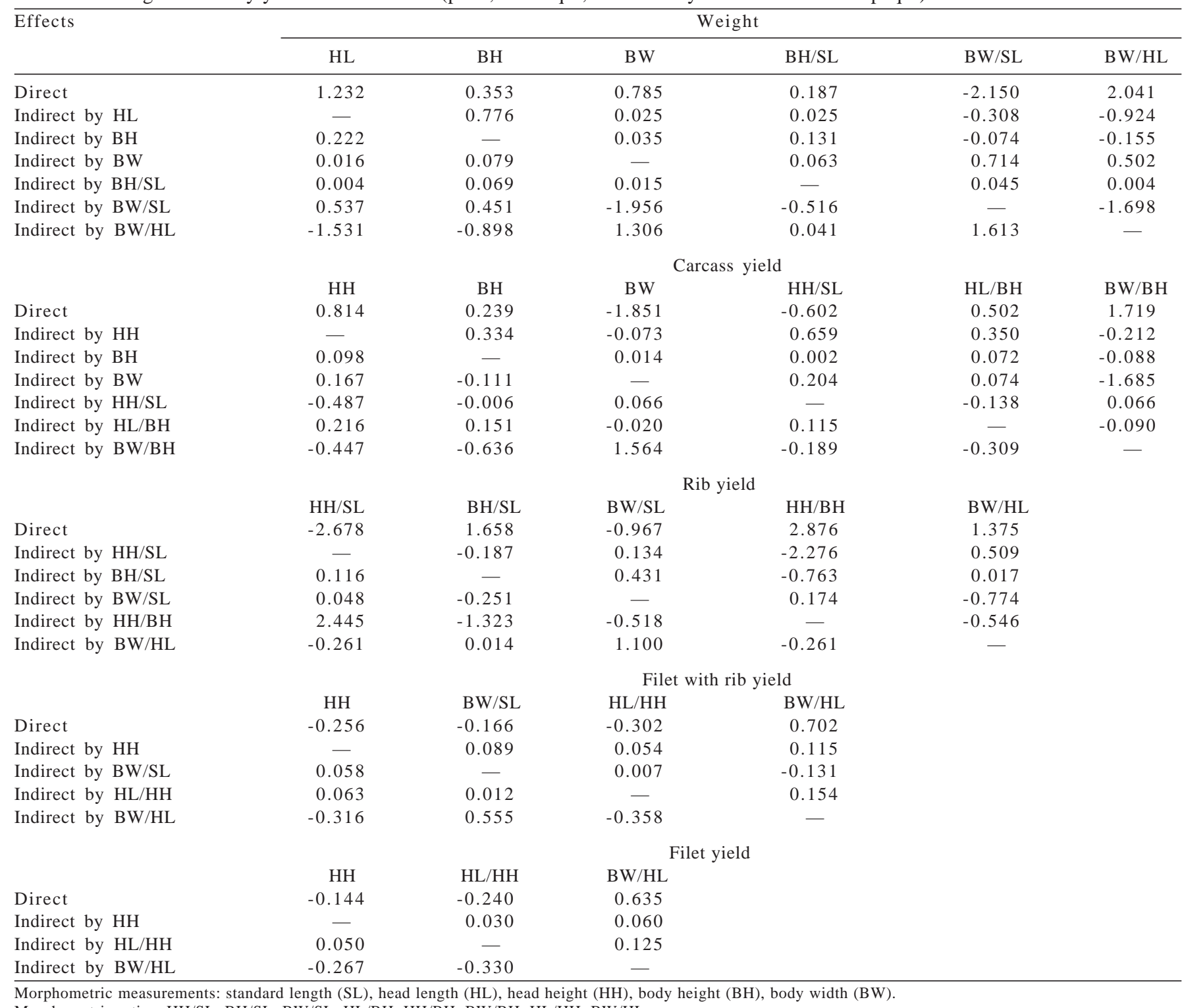

Morphometric ratios: HH/SL, BH/SL, BW/SL, HL/BH, HH/BH, BW/BH, HL/HH, BW/HL.

correlation coefficient (0.48), when used along with BH, may be of interest for estimation of the weight of round fish.

Charo-Karisa et al. (2007) found significant phenotypic correlations between body measurements and weight of tilapia ranging between 0.64 and 0.89 , while Rutten et al. (2004) observed coefficients of 0.76 and 0.91 for phenotypic correlation of height and width with body weight, also for tilapia. Barbosa et al. (2008) indicate standard length as the measure most correlated (0.93) with live weight, for tilapia. Freato et al. (2005), working with piracanjuba Brycon orbignyanus, suggests that standard length, height and body circumference, taken at the insertion of the dorsal fin, are the most suitable for determining the weight of this species, finding a correlation coefficient of $0.89,0.89$ and
0.92, respectively, for these measurements. This divergence of results for morphometric measurements most closely correlated with weight is common, since the species, and even strains of the same species, exhibit variations in their body shape.

Regarding round fish, Serafini (2010), evaluating the performance, along with morphometric and carcass traits, of tambaqui, pacu and their hybrids, observed a superiority for the final weight of tambaqui and the hybrid tambacu in comparison with pacu, while pacu showed the smallest head length and height, confirming the importance of the size of the fish head for weight determination in the studied species. This information is relevant to those branches of the industry that base businesses with suppliers on the 
weight of the animal, since heavier animals are also those with larger heads, which is the body part of lower commercial value.

Measurements of head height (HH), body width (BW) and the HH/SL, HL/BH and BW/BH ratios showed significant correlation coefficients with the carcass yield (Table 1), with higher values observed for $\mathrm{HH}(0.36)$ and $\mathrm{HL} / \mathrm{BH}(0.55)$. The highest percentage of estimated direct effect (91.3\%) was also with respect to $\mathrm{HL} / \mathrm{BH}$, with a path coefficient of 0.502 , showing that this is an important morphometric ratio for the determination of round fish carcass yield.

Similarly to weight, differences in the anatomical shapes of species and strains of the same species result in different body proportions (Contreras-Guzman, 1994).

In a study using tilapia, Diodatti (2008) notes a significant correlation coefficient between morphometric measurements and carcass yield only at the perimeter (0.448), measured at the anal fin insertion. Freato et al. (2005) highlights the height of the body, measured at the pectoral fin insertion, as the most important for carcass yield determination of piracanjuba; however, the author reports a low and negative (-0 35) correlation coefficient, although significant, suggesting that further studies on this body yield would be appropriate. Costa (2011), using path analysis between body shape and body yield of pacu, concludes that morphometric measurements and ratios are not suitable for estimating fish carcass and waste yield.

As found for weight, Serafini (2010) observes that fish with a higher carcass percentage (tambaqui and tambacu) also have the largest head measures, reinforcing the path analysis results, i.e., fish with larger head size, or with heads longer than the body height (CC/A1) are those with highest carcass yield: this is potentially important information for the fish processing industry.

Rib yield showed significant correlation coefficients with the HH/SL, BW/SL, HH/BH and BW/HL ratios (Table 1). The percentages of the direct effect of BW/SL and HH/BH were below $50 \%$, mainly due to indirect effects of BW/HL (1.100) and HH/SL (-2.276), respectively (Table 2); although $\mathrm{HH} / \mathrm{SL}$ has a percentage of direct effect above $50 \%$ on rib yield, the correlation between these variables is relatively low (-0.33), indicating that these three morphometric ratios are inadequate to estimate rib yield. The BW/HL ratio presented the highest correlation coefficient $(0.58)$ and also had a high percentage of direct effect (63.37\%), and is considered to be the morphometric ratio of most interest for estimating the rib yield of round fish.

In the study of Costa (2011), similarly to the results for carcass yield, there was also no good fit between morphometric measurements and ratios and rib yield, producing very low correlation coefficients ranging from 0.04 to 0.17 . This may be explained by the fact that the author worked only with pacu, one of the species of round fish evaluated in this study, which may have resulted in low variability in the fish morphometry, and therefore low adjustments in the analysis.

Regarding filet with rib yield, the head height measurement $(\mathrm{HH})$ and the BW/SL, HL/HH and BW/HL ratios showed significant correlations with this body yield (Table 1). The correlation coefficient between $\mathrm{HH}$ and filet with rib yield was relatively low and negative $(-0.45)$ and, despite having a direct effect at a percentage above $50 \%$, had an indirect effect path coefficient based on BW/HL (-0.316), which was higher than the direct effect coefficient $(-0.256)$ (Table 2). The BW/SL ratio showed a correlation coefficient of 0.49 , reaching almost $80 \%$ of indirect effect, mainly due to BW/HL. The HL/HH ratio showed a correlation coefficient that was slightly higher (-0.6); however, as in the case of $\mathrm{HH}$ and BW/SL, this ratio showed an indirect path coefficient due to BW/HL (-0.358), which was higher than the direct coefficient (-0.302), also a variable of little importance for this body yield. This demonstrates the importance of the BW/HL morphometric ratio which, besides having the highest correlation coefficient (0.84), also had a high percentage for direct effect (83.59\%), indicating that it is a suitable variable for estimating the filet with rib yield.

The filet with rib or bones would be an alternative for the fish processing industry in order to better utilize raw materials, primarily aimed at a less demanding market, since it would be a part with a yield only above the filet.

Similarly to what was observed for filet with rib yield, the filet yield, a part of the fish with the highest economic value, showed significant values for correlation coefficients with $\mathrm{HH}$ and the $\mathrm{HL} / \mathrm{HH}$ and $\mathrm{BW} / \mathrm{HL}$ ratios (Table 1). The measurement related to head size i.e., $\mathrm{HH}(-0.36)$ and $\mathrm{HL} / \mathrm{HH}$ $(-0.54)$, showed negative correlations and high indirect effect percentages: on average $60 \%$, mainly due to BW/HL. Moreover, the indirect effect path coefficients of these measurements due to BW/HL were higher $(-0.267$ for $\mathrm{HH}$ and -0.330 for $\mathrm{HL} / \mathrm{HH}$ ) than the direct effect coefficients: -0.144 for $\mathrm{HH}$ and -0.240 for HL/HH (Table 2). Morphometric ratio L1/CC, with the highest correlation coefficient (0.82) and with a high percentage for direct effect (77.4\%), was shown once again to be an important variable for carcass traits of round fish at the determination of the filet yield.

According to Diodatti et al. (2008), morphometric measurements and ratios usually have low correlations with filet yield, but tilapia, which are longer and wider in the posterior region of the body, have a larger filet percentage. Freato et al. (2005) notes that piracanjubas, with a body 
shape closer to a torpedo, or which are longer and more plump, had a higher filet yield. Costa (2011) states that if the aim is to produce pacu with higher filet yields, then fish with higher BW must be selected. This can be explained by the fact that pacu have a body height and width in greater proportions to standard length (SL) than the other species, as is characteristic of round fish (Serafini, 2010).

Overall, the morphometric measurements and ratios of the heads of round fish, especially head length, were directly related to the weight and carcass yield, i.e., higher HL results in fish that are heavier and with a higher carcass yield. When considering the body yields with higher economic value, morphometric ratio BW/HL always presented high correlation coefficients and high percentages for direct effects with rib yield, filet with rib yield and filet yield, indicating that the larger the dorsal region and the shorter the head of round fish, the higher the yield for rib, filet and filet with rib.

At this point, it is important to note that these results were obtained from the path analysis of fish phenotypic correlations, and it is therefore inappropriate to use these results in a possible improvement programme for round fish carcass traits. For this, a genetic study of these traits would be required, aiming at estimating important parameters for the genetic correlations between the morphometric variables and body yields and heritability, mainly of the morphometric measurements and ratios that were prominent in this study.

According to Turra et al. (2010), information about phenotypic variances and covariances between characteristics are not sufficient for breeding programmes. Genetic covariances are necessary to predict breeding values and to estimate genetic gain, by either directly or indirectly selecting for traits of interest. Velasco et al. (1995), working with tilapia, estimate the heritability of body weight at 0.61 (males) and 0.24 (females), height of 0.61 (males) and 0.57 (females), and standard length at 0.48 (males) and 0.44 (females).

Nguyen et al. (2007) conclude that there is little or no independent genetic variation between morphometric measurements of tilapia (genetic correlations of 0.94 to 0.99 ) and suggest that it would be unnecessary to use all measurements in a selection programme. The same authors estimate the heritability for body weight, length, height and width, which varied between 0.20 and 0.35 , and also estimate high correlations (from 0.91 to 0.96 ) between sexes for all body measurements and weight, indicating that is not necessary to have separate breeding programmes by gender.

Rutten et al. (2005) were the first to genetically evaluate the filet yield of Nile tilapia (Turra et al., 2010) and, in their study, the filet yield is genetically correlated with width
(0.98), with filet weight (0.81) and with body weight (0.74), and these values were considered completely satisfactory for the indirect selection process.

\section{Conclusions}

The head length and body height measurements are important for determining the weight of round fish. The ratio of head length and body height is directly associated with carcass yield. To determine the most important carcass traits, i.e., filet, rib and filet with rib yields, the body width/ head length ratio is the most appropriate morphometric variable and can be used directly by the fish industry. In addition, this morphometric ratio could be used in breeding programmes as a measure of indirect selection for fish with better carcass traits, but first, it is necessary to conduct a genetic study to provide information about the heritability and genetic correlation of this variable with the body yields of interest.

\section{Acknowledgements}

The authors are grateful for the support from Instituto Federal do Espírito Santo, Campus Colatina.

\section{References}

ABIMORAD, E.G.; CARNEIRO, D.J. Métodos de coleta de fezes e determinação dos coeficientes de digestibilidade da fração protéica e da energia de alimentos para o pacu, Piaractus mesopotamicus (Holmberg, 1887). Revista Brasileira de Zootecnia, v.33, n.5, p.1101-1109, 2004.

BARBOSA, A.C.B.; CARNEIRO, P.L.S.; MALHADO, C.H.M. et al. Desempenho e avaliação sensorial de duas linhagens de Tilápia do Nilo. Revista Científica de Produção Animal, v.10, n.1, p.50-59, 2008.

CHARNET, R.; LUNA, C.A.L.; CHARNET, E.M.R. et al. Análise de modelos de regressão linear com aplicações. 2.ed. Campinas: Editora da UNICAMP, 2008. 356p.

CHARO-KARISA, H.; BOVENHUIS, H.; REZK, M.A. et al. Phenotypic and genetic parameters for body measurements, reproductive traits and gut length of Nile tilapia (Oreochromis niloticus) selected for growth in low-input earthen ponds. Aquaculture, v.273, p.15-23, 2007.

COIMBRA J.L.M.; BENIN, G.; VIEIRA, E.A. et al. Conseqüências da multicolinearidade sobre a análise de trilha em canola. Ciência Rural, v.35, n.2, p.347-352, 2005.

CONTRERAS-GUZMÁN, E.S. Bioquímica de pescados e derivados. 1.ed. Jaboticabal: Editora FUNEP, 1994. 409p.

COSTA, A.C. Medidas morfométricas na avaliação de pesos e rendimentos corporais de pacu Piaractus mesopotamicus e tambaqui Colossoma macropomum. 2011. 64f. Dissertação (Mestrado em Zootecnia) - Universidade Federal de Lavras, Lavras.

CREPALDI, D.V.; TEIXEIRA, E.A.; FARIA, P.M.C. et al. Rendimento de carcaça em surubim (Pseudoplatystoma spp.) avaliado por ultra-som. Revista Brasileira de Saúde e Produção Animal, v.9, n.4, p.813-824, 2008. 
CRUZ, C.D. Programa GENES, versão windows: aplicativo computacional em genética e estatística. Viçosa, MG: Universidade Federal de Viçosa, 2001. 648p.

CRUZ, C.D.; CARNEIRO, P.C.S. Modelos biométricos aplicados ao melhoramento genético. Viçosa, MG: Universidade Federal de Viçosa, 2003. 585p.

DIODATTI, F.C.; FREITAS, R.T.F.; FREATO, T.A. et al. Parámetros morfométricos en el rendimiento de los componentes corporales de tilapia del nilo (Oreochromis oreochromis). Anales de Veterinaria de Murcia, v.24, p.45-55, 2008.

FREATO, T.A.; FREITAS, R.T.F.; DOS SANTOS, V.B. et al. Efeito do peso de abate nos rendimentos do processamento da piracanjuba (Brycon orbignyanus, valenciennes, 1849). Ciência e Agrotecnologia, v.29, n.3, p.676-682, 2005.

INSTITUTO BRASILEIRO DO MEIO AMBIENTE E DOS RECURSOS NATURAIS RENOVÁVEIS - IBAMA. Diretoria de Fauna e Recursos Pesqueiros. Estatística da pesca, 2005: grandes regiões e unidades da federação. Brasília: IBAMA, 2005. p.147.

JOMORI, R.K.; DUCATTI, C.; CARNEIRO, D.J. et al. Stable carbon $(\delta 13 \mathrm{C})$ and nitrogen $(\delta 15 \mathrm{~N})$ isotopes as natural indicators of live and dry food in Piaractus mesopotamicus (Holmberg, 1887) larval tissue. Aquaculture Research, v.39, p.370-381, 2008.

LOURES, B.T.R.R.; RIBEIRO, R.P.; VARGAS, L. et al. Manejo alimentar de alevinos de tilápia do Nilo, Oreochromis niloticus, associado às variáveis físicas, químicas e biológicas do ambiente. Acta Scientiarum, v.23, n.4, p.877-883, 2001.

NGUYEN, N.H.; KHAW, H.L.; PONZONI, R.W. et al. Sexual dimorphism and body shape be altered in Nile tilapia (Oreochromis niloticus) by genetic means. Aquaculture, v.272, n.S1, p.S38-S46, 2007.

PEDRAZZANI, A.S.; CARNEIRO, P.C.F.; KIRSCHNIK, P.G. et al. Impacto negativo de secção de medula e termonarcose no bemestar e na qualidade da carne da tilápia-do-Nilo. Revista Brasileira de Saúde e Produção Animal, v.10, n.1, p.188-197, 2009.

RUTTEN, M.J.M.; BOVENHUIS, H.; KOMEN, H. Genetic parameters for fillet traits and body measurements in Nile tilapia
(Oreochromis niloticus L.). Aquaculture, v.246, p.125-132, 2005 a.

RUTTEN, M.J.M.; KOMEN, H.; BOVENHUIS, H. Longitudinal genetic analysis of Nile tilapia (Oreochromis niloticus L.) body weight using a random regression model. Aquaculture, v.246, p.101-113, 2005b.

RUTTEN, M.J.M.; BOVENHUI, H.; KOMEN, H. Modeling fillet traits based on body measurements in three Nile tilapia strains (Oreochromis niloticus L.). Aquaculture, v.231, p.113-122, 2004.

SANG, N.V.; THOMASSEN M.; KLEMETSDAL, G. et al. Prediction of fillet weight, fillet yield, and fillet fat for live river catfish (Pangasianodon hypophthalmus). Aquaculture, v.288, p.166-171, 2009.

SERAFINI, M.A. Cruzamento dialélico interespecífico entre pacu Piaractus mesopotamicus e tambaqui Colossoma macropomum. 2010. 68f. Tese (Doutorado em Zootecnia) Universidade Federal de Lavras, Lavras.

SIGNOR, A.A.; BOSCOLO, W.R.; FEIDEN, A. et al. Proteína e energia na alimentação de pacus criados em tanques-rede. Revista Brasileira de Zootecnia, v.39, n.11, p.2336-2341, 2010.

SILVA, F.V.; SARMENTO, N.L.A.F.; VIEIRA, J.S. et al. Características morfométricas, rendimentos de carcaça, filé, vísceras eresíduos em tilápias-do-nilo em diferentes faixas de peso. Revista Brasileira de. Zootecnia, v.38, n.8, p.1407-1412, 2009.

SOUZA M.L.R.; LIMA, S.; FURUYA, W.M. et al. Estudo da carcaça do bagre africano (Clarias gariepinus) em diferentes categorias de peso. Acta Scientiarum, v.21, n.3, p.637-644, 1999.

TURRA, E.M.; OLIVEIRA, D.A.A.; TEIXEIRA, S.A. et al. Uso de medidas morfométricas no melhoramento genético do rendimento de filé da tilápia do Nilo (Oreochromis niloticus). Revista Brasileira de Reprodução Animal, v.34, n.1, p.29-36, 2010.

VELASCO, R.R.; JANAGAP, C.C.; DE VERA, M.P. et al. Genetic improvement of farmed tilapias: estimation of heritability of body and carcass traits of nile tilapia (Oreochromis niloticus). Aquaculture, v.137, p.280-281, 1995. 